\title{
Effect of Date of Sowing and Crop Geometry on Growth and Production Potential of Cluster Bean under Rainfed Condition of Gujarat
}

\author{
K. K. Dhedhi", N. N. Chaudhari, R. P. Juneja and J. S. Sorathiya
}

Pearl Millet Research Station, Junagadh Agricultural University, Jamnagar, Gujarat (361 006), India

\section{Article History}

Manuscript No. AR1633

Received in $1^{\text {st }}$ July, 2016

Received in revised form $15^{\text {th }}$ July, 2016

Accepted in final form $30^{\text {th }}$ July, 2016

\section{Correspondence to}

"E-mail:kkdhedhi@rediffmail.com

\section{Keywords}

Cluster bean, date of sowing, spacing, growth, yield

\begin{abstract}
A field experiment was conducted under rainfed condition during kharif seasons of 2013 and 2014 at Pearl millet Research Station, Junagadh Agricultural University, Jamnagar, Gujarat (India) to find out the optimum time of sowing and row spacing for production potential of cluster bean (var. Gujarat Guar 2). The experimental field was laid out in split plot design with four replications. There were six treatment combinations consisting of three dates of sowing ( $1^{\text {st }} \mathrm{July}, 11^{\text {th }} \mathrm{July}$ and $\left.21^{\text {st }} \mathrm{July}\right)$ and two spacing $\left(30 \times 10 \mathrm{~cm}^{2}\right.$ and $\left.45 \times 10 \mathrm{~cm}^{2}\right)$. Pooled over two years results revealed that all the characters studied were markedly affected by sowing dates and row spacing. Data of all traits under studied were gradually decreased with delaying sowing date from $1^{\text {st }}$ July to $21^{\text {st }}$ July. The highest seed yield $\left(12.19 \mathrm{q} \mathrm{ha}^{-1}\right)$ was obtained when the crop sown on $1^{\text {st }}$ July which was significantly superior to other dates of sowing. Closer row spacing gave statically higher seed yield than wider spacing. The interaction effects of dates of sowing $\times$ row spacing were found non-significant for all the traits studied. However, sowing of cluster bean on $1^{\text {st }}$ July in a spacing of $30 \times 10 \mathrm{~cm}^{2}$ gave the highest seed yield ( $\left.12.74 \mathrm{q} \mathrm{ha}^{-1}\right)$ as compared to other treatments. This may be due to higher number of pods plant ${ }^{-1}$, number of clusters plant ${ }^{-1}$, number of pods cluster ${ }^{-1}$, plant height and test weight.
\end{abstract}

\section{Introduction}

Cluster bean [Cyamopsis tetragonoloba (L.) Taub] $(2 n=14)$ is an under exploited leguminous crop belonging to the family Fabaceae. It is commonly known as Guar, Chavli kayi, Khutti. Cluster bean is grown in kharif season in arid and semi arid regions of India. It is a drought hardy, deep rooted, summer annual legume. Like the other legumes, guar is an excellent soil-binding crop with respect to available nitrogen. Guar is one of the most important and potential vegetable cum industrial crop grown for its tender pods for vegetable purpose and for endospermic gum. It is a principal source of galactomannan (guar gum) for the country and has numerous food and industrial uses. It is also used for green manuring, feed for cattle and poultry, as vegetable and fodder. Guar gum is used in mining, petroleum drilling and textile manufacturing sector, is obtained from the endosperm of the seed of the plant. Endosperm of the guar seed which accounts for $30 \%$ of the seed weight (Sabahelkheir et al., 2012). The guar bean is principally grown in India, Pakistan, U.S., Australia and Africa. India produces 2.5 to $3.5 \mathrm{mt}$ of guar annually, making it the largest producer with about $80 \%$ of world production (Kalyani, 2012). Rajasthan is a major Guar producing State in India followed by
Gujarat and Haryana and small contributions from the states of Uttar Pradesh, Punjab and Madhya Pradesh.

Guar yield in our country is extremely low and has been static over the past several decades. This may probably be due to the fact that low and erratic distribution of rainfall, extreme temperatures coupled with very few investigations made for agronomic practices. Appropriate sowing time helps to more efficient use of water, sunshine hours and higher photosynthetic rates. Kalyani (2012) reported that the sowing of guar during first fortnight of July was produced significantly higher seed yield than the crop sown other dates. (Gresta et al., 2013) depicted that mid-May planting of guar was produced the highest seed yield in Mediterranean environment of Italy. (Singla et al., 2016) reported that the guar planted under mid-June resulted in higher number of clusters plant- ${ }^{-1}$, pods

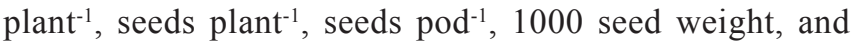
harvest index (HI) than early-July and late-July plantings. The mid-June planting of guar was produced significantly higher seed yield than early-July and late-July. Optimum row spacing is one of the major management variables under dry land conditions. In water deficits regions large canopy growth may be disadvantageous as it may exhaust the available soil 
moisture more rapidly from root zone (Garg et al., 2005). In Gujarat, the area under cluster bean is low but increasing year after year due to drought hardy nature and better performance under moisture stress situation compared traditional legume crops. Therefore, it is of paramount importance to identify and develop agronomical practices that influences the production potential of Guar.

Considering the above points in view, the experiment was undertaken on effect of date of sowing and crop geometry on growth and production potential of cluster bean under rainfed condition of Gujarat at Pearl Millet Research Station, Junagadh Agricultural University, Jamnagar (India) during kharif seasons of 2013 and 2014.

\section{Materials and Methods}

A field experiment was conducted on cluster bean (var. Gujarat Guar 2) under rainfed condition during kharif seasons of 2013 and 2014 at Pearl Millet Research Station, Junagadh Agricultural University, Jamnagar, Gujarat (India). The experimental site is located at $22^{\circ} .28 \mathrm{~N}$ latitude and $70^{\circ} .00 \mathrm{E}$ longitudes at a height of $7.77 \mathrm{~m}$ amsl. The experiment was laid out in spilt plot design with four replications. The treatments comprised three dates of sowing viz., $1^{\text {st }}$ July $\left(\mathrm{D}_{1}\right), 11^{\text {th }}$ July $\left(\mathrm{D}_{2}\right)$ and $21^{\text {st }} \mathrm{July}\left(\mathrm{D}_{3}\right)$ allotted randomly in the main plots and two spacing in the sub plots viz., $30 \times 10 \mathrm{~cm}^{2}\left(\mathrm{~S}_{1}\right)$ and $45 \times 10$ $\mathrm{cm}^{2}\left(\mathrm{~S}_{2}\right)$. Recommended dose of fertilizer at the rate of $20 \mathrm{~kg}$ $\mathrm{N}$ and $40 \mathrm{~kg} \mathrm{P}_{2} \mathrm{O}_{5}$ ha $^{-1}$ was applied uniformly as basal dose at each sowing time. Micronutrient like sulphur (S) was applied at the rate of $20 \mathrm{~kg} \mathrm{ha}^{-1}$ in field experiment as basal dose. Seed was soaked in streptocycline (100 ppm) solution for 45 minutes at the time of sowing. Pre-emergence application of herbicide stomp was applied at @ $1.5 \mathrm{~kg} \mathrm{ha}^{-1}$ after one day of sowing. Other cultural practices and protection measures were given according to the recommended package of practices. The gross or net plot size was $4.5 \times 5.0 \mathrm{~m}^{2}$. The observations on growth and yield parameters were recorded on five randomly selected plants in each plot for different date of sowing. The data collected was subjected to analysis of variance technique as described by (Steel et al., 1997).

\section{Results and Discussion}

The data pooled over two years pertaining to seed yield and other related traits are presented in Table 1 . and have been discussed in the following sub heads:

\subsection{Effect of years}

A perusal of revealed that the years were non-significant for most of the traits studied except for plant height, number of pods plant ${ }^{-1}$, number of clusters plant ${ }^{-1}$ and seed yield.

\subsection{Effect of sowing time}

Among the dates of sowing, $1^{\text {st }}$ July sowing time took significantly more number of days to initiation of flowering (30.56 days) in cluster bean. The crop sown during $21^{\text {st }}$ July resulted in the earliest flowering (28.94 days). The crop sown during $11^{\text {th }}$ and $21^{\text {st }}$ July was significantly differed with each other in regards of days to initiation of flowering. The highest plant height $(98.82 \mathrm{~cm})$ was recorded with the crop sown during $1^{\text {st }} \mathrm{July}$, which was significantly higher over $11^{\text {th }}$ and $21^{\text {st }}$ July sowing dates. The shortest plant height $(55.29 \mathrm{~cm})$ was noticed with the crop sown during $21^{\text {st }}$ July. Later sown cluster bean experienced low temperatures and excessive rainfall during the crop growth period, which adversely affected the plant growth, thereby decreased the plant height. With regards to yield attribute traits, the cluster bean sown during $1^{\text {st }}$ July recorded significantly higher number of pods plant ${ }^{-1}$ (132.38), number of clusters plant ${ }^{-1}$ (21.51) and number of pods cluster-1 ${ }^{-1}(6.15)$ as compared to other dates of sowing, which in turn differed significantly with each other. The crop sown during $21^{\text {st }}$ July recorded the lowest number of pods plant ${ }^{-1}$ (49.81), number of clusters plant ${ }^{-1}(13.73)$ and number of pods cluster-1 ${ }^{-1}(3.60)$. The maximum 1000-seed weight (30.20 gm) was recorded with $1^{\text {st }}$ July sowing time and it was significantly higher over $21^{\text {st }}$ July sowing time. However, the crop sown during $1^{\text {st }}$ and $11^{\text {th }}$ July as well as $11^{\text {th }}$ and $21^{\text {st }}$ July sowing times did not differ significantly with each other, in respect of test weight. The differences among dates of sowing were non-significant in respect of germination percent, seedling length and seedling vigour index.

The data (Table 1) revealed that the highest seed yield (12.19 $\mathrm{q} \mathrm{ha}^{-1}$ ) was produced, when cluster bean was sown on $1^{\text {st }}$ July, which was significantly superior over $11^{\text {th }}$ July sowing date $\left(8.76 \mathrm{q} \mathrm{ha}^{-1}\right)$. While, $11^{\text {th }}$ and $21^{\text {st }}$ July sowing dates was at par with each other. The seed yield was gradually decreased with later sowing times. Higher seed yield with $1^{\text {st }}$ July sowing date was mainly due to enhanced yield attributes such as more number of pods plant ${ }^{-1}$, number of clusters plant ${ }^{-1}$, number of pods cluster ${ }^{-1}$ and test weight, which was due to favorable weather conditions experienced by the crop during the crop growth period. The lowest seed yield $\left(6.73 \mathrm{q} \mathrm{ha}^{-1}\right)$ obtained during $21^{\text {st }}$ July sowing time might be due to reduced photosynthetic activity and translocation of assimilates as a result of abnormal weather conditions, which affected pod development and seed formation. The seed yield increase recorded with $1^{\text {st }}$ and $11^{\text {th }}$ July sowing dates over $21^{\text {st }}$ July sowing date was to the tune of 81.13 and $30.16 \%$, respectively. Similar effect of dates of sowing on seed yield in cluster bean has been reported by Bains and Dhillon (1975), (Singh et al., 1979 ; Sharma et al., 1984; Taneja et al., 1984; Jain et al., 1987) Bhadoria and Chauhan (1994), (Taneja et al., 1995; Ali et al., 2004; Kalyani et al., 2007; Jagtap et al., 2011); Kalyani (2012), (Gresta et al., 2013; Deka et al., 2015; Singla et al., 2016). The years $\times$ dates of sowing interaction effects were found 


\begin{tabular}{|c|c|c|c|c|c|c|c|c|c|c|}
\hline Treatment & $\begin{array}{l}\text { Days to } \\
\text { initiation of } \\
\text { flowering }\end{array}$ & $\begin{array}{c}\text { Plant } \\
\text { height } \\
(\mathrm{cm})\end{array}$ & $\begin{array}{c}\text { Number } \\
\text { of pods } \\
\text { plant }^{-1}\end{array}$ & $\begin{array}{c}\text { Number } \\
\text { of clusters } \\
\text { Plant }^{-1}\end{array}$ & $\begin{array}{l}\text { Number } \\
\text { of pods } \\
\text { cluster }^{-1}\end{array}$ & $\begin{array}{c}\text { 1000-seed } \\
\text { Weight } \\
(\mathrm{gm} .)\end{array}$ & $\begin{array}{c}\text { Germi- } \\
\text { nation } \\
(\%)\end{array}$ & $\begin{array}{l}\text { Seedling } \\
\text { length } \\
(\mathrm{cm})\end{array}$ & $\begin{array}{l}\text { Seedling } \\
\text { vigour } \\
\text { Index }(\%)\end{array}$ & $\begin{array}{c}\text { Seed } \\
\text { yield } \\
\left(\mathrm{q} \mathrm{ha}^{-1}\right) \\
\end{array}$ \\
\hline \multicolumn{11}{|l|}{ Year $(\mathrm{Y})$} \\
\hline $\mathrm{Y}_{1}$ & 29.83 & 82.26 & 97.17 & 18.94 & 5.00 & 29.72 & 91.83 & 15.28 & 1403 & 9.81 \\
\hline $\mathrm{Y}_{2}$ & 29.71 & 68.40 & 85.58 & 16.60 & 4.88 & 29.55 & 90.08 & 11.90 & 1073 & 8.64 \\
\hline $\mathrm{CD}^{*}$ for $\mathrm{Y}$ & NS & 3.15 & 8.77 & 1.65 & NS & NS & NS & NS & NS & 0.38 \\
\hline \multicolumn{11}{|c|}{ Date of sowing (D) } \\
\hline $\mathrm{D}_{1}$ & 30.56 & 98.82 & 132.38 & 21.51 & 6.15 & 30.20 & 91.94 & 13.90 & 1278 & 12.19 \\
\hline $\mathrm{D}_{2}$ & 29.81 & 71.87 & 91.94 & 18.08 & 5.09 & 29.74 & 91.25 & 13.77 & 1260 & 8.76 \\
\hline $\mathrm{D}_{3}$ & 28.94 & 55.29 & 49.81 & 13.73 & 3.60 & 28.96 & 89.69 & 13.10 & 1175 & 6.73 \\
\hline $\mathrm{CD}$ for $\mathrm{D}$ & 0.45 & 3.86 & 10.74 & 2.02 & 0.25 & 0.93 & NS & NS & NS & 3.18 \\
\hline For $\mathrm{Y} \times \mathrm{D}$ & NS & NS & NS & NS & NS & NS & NS & NS & NS & 0.66 \\
\hline \multicolumn{11}{|c|}{ Crop geometry (S) } \\
\hline $\mathrm{S}_{1}$ & 29.37 & 77.31 & 95.33 & 18.18 & 5.04 & 29.89 & 91.13 & 13.78 & 1258 & 9.74 \\
\hline $\mathrm{S}_{2}$ & 30.17 & 73.35 & 87.42 & 17.37 & 4.85 & 29.38 & 90.79 & 13.39 & 1218 & 8.72 \\
\hline $\mathrm{CD}$ for $\mathrm{S}$ & NS & 2.50 & 6.62 & 0.66 & NS & NS & NS & NS & NS & NS \\
\hline For $\mathrm{Y} \times \mathrm{S}$ & 0.48 & NS & NS & NS & NS & NS & NS & NS & NS & 0.71 \\
\hline \multicolumn{11}{|c|}{ Interaction effects } \\
\hline \multirow[t]{2}{*}{$\mathrm{D}_{1}$} & 30.13 & 101.75 & 139.50 & 22.35 & 6.24 & 30.78 & 92.63 & 13.90 & 1288 & 12.74 \\
\hline & 31.00 & 95.90 & 125.25 & 20.68 & 6.06 & 29.62 & 91.25 & 13.89 & 1268 & 11.65 \\
\hline \multirow[t]{2}{*}{$\mathrm{D}_{2}$} & 29.25 & 73.00 & 94.88 & 18.30 & 5.18 & 29.88 & 91.63 & 14.22 & 1306 & 9.33 \\
\hline & 30.38 & 70.75 & 89.00 & 17.85 & 5.00 & 29.61 & 90.88 & 13.32 & 1215 & 8.19 \\
\hline \multirow[t]{2}{*}{$\mathrm{D}_{3}$} & 28.75 & 57.18 & 51.63 & 13.88 & 3.70 & 29.02 & 89.13 & 13.23 & 1178 & 7.16 \\
\hline & 29.13 & 53.41 & 48.00 & 13.58 & 3.50 & 28.91 & 90.25 & 12.97 & 1172 & 6.30 \\
\hline \multirow{2}{*}{$\begin{array}{l}C D \text { for } D \times S \\
\text { For } Y \times D \times S\end{array}$} & NS & NS & NS & NS & NS & NS & NS & NS & NS & NS \\
\hline & NS & NS & NS & NS & NS & NS & NS & NS & NS & NS \\
\hline
\end{tabular}

Where: * $\mathrm{CD}(p=0.05) ; \mathrm{Y}_{1}:$ Kharif-2013; $\mathrm{Y}_{2}:$ Kharif-2014; $\mathrm{D}_{1}: 1^{\text {st }}$ July; $\mathrm{D}_{2}: 11^{\text {th }}$ July; $\mathrm{D}_{3}: 21^{\text {st }}$ July; $\mathrm{S}_{1}: 30 \times 10 \mathrm{~cm}^{2} ; \mathrm{S}_{2}: 45 \times 10 \mathrm{~cm}^{2}$

non-significant for all the characters studied except seed yield.

\subsection{Effect of rows spacing}

The differences between $30 \mathrm{~cm}$ and $45 \mathrm{~cm}$ row spacing were significant for plant height, number of pods plant ${ }^{-1}$ and number of clusters plant ${ }^{-1}$; whereas, it was non-significant for days to initiation of flowering, number of pods cluster-1 ${ }^{-1} 1000$-seed weight, germination percent (\%), seedling length, seedling vigour index and seed yield. However, seed yield, number of pods cluster ${ }^{-1}, 1000$-seed weight, germination percent (\%), seedling length and seedling vigour index were recorded numerically higher in $30 \mathrm{~cm}$ row spacing as compared to 45 $\mathrm{cm}$ spacing crop sown. The highest plant height $(77.31 \mathrm{~cm})$ was recorded with $30 \mathrm{~cm}$ row spacing which was significantly higher than the $45 \mathrm{~cm}$ row spacing apart. The maximum number of pods plant ${ }^{-1}$ (95.33) and number of clusters plant ${ }^{-1}$ (18.18) was observed in a row spacing of $30 \mathrm{~cm}$ which was also significantly higher than $45 \mathrm{~cm}$ row spacing apart. Among the other crop production factors, the row spacing contributes much to a proper crop stand establishment in the field. Production may be favorable on narrowing spacing. Narrowing row spacing might give the plant more erect upright plant architecture (Akhtar et al., 2012). Williams (1960) conducted a field experiment to see the effect of row spacing and plant density on Guar and found that crop grown in $50 \mathrm{~cm}$ spaced rows produced higher seed yield than grown $75 \mathrm{~cm}$ and 100 $\mathrm{cm}$ rows apart. Hymowitz and Matlock (1964) found the best spacing for Guar cultivars used in their study was $50 \mathrm{~cm}$. Bains and Dhillon (1975) reported that Guar seed yield reductions occurred when row to row spacing 's was increased from $30 \mathrm{~cm}$ to $45 \mathrm{~cm}$. (Sharma et al., 1984) recorded the highest seed yield in rows $30 \mathrm{~cm}$ spaced than those grown in rows $45 \mathrm{~cm}$ to $60 \mathrm{~cm}$ apart in cluster bean. (Akhtar et al., 2012) manifested that the highest seed yield in guar was produced in $30 \mathrm{~cm}$ rows spacing 
than $45 \mathrm{~cm}$ and $60 \mathrm{~cm}$ spaced apart. In contrast to present results, (Jagtap et al., 2011) recorded low seed yield in $30 \mathrm{~cm}$ spaced row as compared to $45 \mathrm{~cm}$ apart in guar. The years $\times$ row spacing interaction effects were found non-significant for all the characters studied.

\subsection{Effect of dates of sowing $\times$ rows spacing}

The interaction effects of years $\times$ dates of sowing $\times$ rows spacing as well as dates of sowing $\times$ rows spacing was found nonsignificant for all the characters under studied. However, the highest seed yield (12.74 $\left.\mathrm{q} \mathrm{ha}^{-1}\right)$ in Guar was produced, when crop was sown on $1^{\text {st }}$ July in a spacing of $30 \times 10 \mathrm{~cm}^{2}$. The maximum plant height $(101.75 \mathrm{~cm}), 1000$-seed weight $(30.78$ gm), number of pods plant ${ }^{-1}$ (139.50), number of clusters plant $^{-1}$ (22.35), number of pods cluster ${ }^{-1}(6.24)$ and the highest germination percent $(92.63 \%)$ was recorded in cluster bean with $1^{\text {st }}$ July sowing in a spacing of $30 \times 10 \mathrm{~cm}^{2}$.

\section{Conclusion}

Sowing on $1^{\text {st }}$ July and $30 \times 10 \mathrm{~cm}^{2}$ spacing was suitable for higher production of cluster bean under rainfed condition of Gujarat (India).

\section{References}

Akhtar, L.H., Bukhari, S., Sultan, S.D., Minhas, R., 2012. Response of new guar strains to various row spacing. Pakistan Journal of Agricultural Sciences 49(4), 469-471.

Ali, Z., Zahid, M.S., Muhammad, Z.H., Muhammad, B., 2004. Sowing dates effects on growth, development and yield of Guar (Cyamopsis tetragonoloba (L.) Taub) under rainfed conditions of pothowar region. Journal of Agricultural Research 42(1), 33-40.

Bains, D.S., Dhillon, D.S., 1975. The influence of sowing dates and row spacing patterns on the performance of two varieties of cluster bean (Cyamopsis tetragonoloba (L.) Taub). Journal of Research Punjab Agricultural University 14(2), 157-161.

Bhadoria, R.B.S., Chauhan, V.S., 1994. Response of cluster bean (Cyamopsis tetragonoloba (L.) Taub) to dates of sowing and spacing. Indian Journal of Agronomy 39(1), 156-157.

Deka, K.K., Das, M.R., Bora, P., Mazumder, N., 2015. Effect of sowing dates and spacing on growth and yield of cluster bean (Cyamopsis tetragonoloba) in subtropical climate of Assam, India. Indian Journal of Agricultural Research 49(3), 250-254.

Garg, B.K., Burman, U., Kathju, S., 2005. Physiological aspects of drought tolerance in cluster bean and strategies for yield improvement under arid conditions. Journal of Arid Legumes 2(1), 61-66.

Gresta, F., Sortino, O., Santonoceto, C., Issi, L., Formantici, C., Galante, Y., 2013. Effect of sowing times on seed yield, protein and galactomannans content of four varieties of Guar (Cyamopsis tetragonoloba (L.) Taub) in a Mediterranean environment. Industrial Crops and Products 41, 46-52.

Hymowitz, T., Matlock, S., 1964. Guar, seed plant and population studies. Oklahoma Technology Bulletin B-108, 35.

Jain, V., Yadav, B.D., Sharma, B.D., Taneja, K.D., 1987. Effect of dates of sowing, row spacing and varieties on yield and quality of cluster bean (Cyamopsis tetragonoloba (L.) Taub). Indian Journal of Agronomy 32(4), 378-382.

Jagtap, D.N., Waghule, L.D., Bhale, V.M., 2011. Effect of sowing time, row spacing and seed rate on production potential of cluster bean. Advance Research Journal of Crop Improvement 2(1), 27-30.

Kalyani, D.L., 2012. Performance of cluster bean genotypes under varied time of sowing. Legume Research 35(2), 154-158.

Kalyani, D.L., Reddy, P., Prasanthi, L., 2007. Effect of dates of sowing on yield and quality of rainfed guar (Cyamopsis tetragonoloba (L.) Taub) cultivars. Journal of Arid Legumes 4(1), 40-42.

Sabahelkheir, M.K., Abdalla, A.H., Nouri, S.H., 2012. Quality assessment of guar gum (Endosperm) of guar (Cyamopsis tetragonoloba). ISCA Journal of Biological Sciences 1, 67-70.

Sharma, B.D., Tangeja, K.D., Kairon, M.S., Jain, V., 1984. Effect of dates of sowing and row spacing on yield and quality of cluster bean (Cyamopsis tetragonoloba (L.) Taub). Indian Journal of Agronomy 29, 557-558.

Singh, K., Kumar, S., Taneja, K.D., 1979. Effect of different sowing dates on the seed yield of different varieties of Guar (Cyamopsis tetragonoloba (L.) Taub). Haryana Agricultural University Journal of Research 9(4), 312-316.

Singla, S., Kulbhushan, Grover., Sangamesh, V. Angadi, Sultan H. Begna, Brain S., Dawn Van Leeuwen, 2016. Growth and yield of Guar (Cyamopsis tetragonoloba L.) genotypes under different planting dates in the Semi-Arid Southern high plains. American Journal of Plant Sciences 7, 1246-1258.

Steel, R.G.D., Torrie, J.H., Dickey, D.A., 1997. Principles and Procedures of Statistics: A biometrical approach, 3rd Edition. McGraw Hill Book Company, New York, USA.

Taneja, K.D., Bishnoi, O.P., Rao, V.U.M., Niwas, R., 1995. Effect of environment on growth and yield of cluster bean. Crop Research Hisar 9(1), 159-162.

Taneja, K.D., Saini, M.L., Sharma, B.D., 1984. Effect of dates of sowing and row spacing on the seed yield of guar. Forage Research 10(2), 115-117.

Williams, C., 1960. A cultural study of guar involving three varieties, three row spacing and rates of planting. M.Sc. Thesis, Oklahoma State University, Stillwater, 25. 